\title{
Coping with persistent environmental problems: systemic delays in reducing eutrophication of the Baltic Sea
}

\author{
$\underline{\text { Riku Varjopuro }}^{1}, \underline{\text { Eugeniusz Andrulewicz }}^{2}, \underline{\text { Thorsten Blenckner }}^{3}, \underline{\text { Tobias Dolch }}^{4}, \underline{\text { Anna-Stiina Heiskanen }}{ }^{5}, \underline{\text { Mia Pihlajamäki }}^{1}, \underline{\text { Urs }}$ \\ $\underline{\text { Steiner Brandt }}^{6}, \underline{\text { Matilda Valman }}^{3,7,8}$ Kira Gee $^{9,10}$, Tavis Potts $^{1,12}$ and Iwona Psuty $^{2}$
}

\begin{abstract}
In this paper we focus on systemic delays in the Baltic Sea that cause the problem of eutrophication to persist. These problems are demonstrated in our study by addressing three types of delays: (1) decision delay: the time it takes for an idea or perceived need to be launched as a policy; (2) implementation delay: the time from the launch of a policy to the actual implementation; (3) ecosystem delay: the time difference between the implementation and an actual measurable effects. A policy process is one characterized by delays. It may take years from problem identification to a decision to taking action and several years further for actual implementation. Ecosystem responses to measures illustrate that feedback can keep the ecosystem in a certain state and cause a delay in ecosystem response. These delays can operate on decadal scales.

Our aim in this paper is to analyze these systemic delays and especially to discuss how the critical delays can be better addressed in marine protection policies by strengthening the adaptive capacity of marine protection. We conclude that the development of monitoring systems and reflexive, participatory analysis of dynamics involved in the implementation are keys to improve understanding of the systemic delays. The improved understanding is necessary for the adaptive management of a persistent environmental problem. In addition to the state of the environment, the monitoring and analysis should be targeted also at the implementation of policies to ensure that the societies are investing in the right measures.
\end{abstract}

Key Words: adaptive management; Baltic Sea; ecosystem delays; monitoring of implementation

\section{INTRODUCTION}

Eutrophication in the Baltic Sea is a well-known and widely studied problem. Its consequences, such as water quality degradation, algal blooms, alteration of habitats and species composition, have been increasingly observed since the 1980s. Most of the main causes of eutrophication are known and there is a willingness to tackle them. The issue has been addressed by various national and intergovernmental policies. The international convention on protection of the Baltic Sea, HELCOM, has dealt with the problem since the 1970s. HELCOM's present Baltic Sea Action Plan (BSAP) has been operational since 2007 (Backer et al. 2010, Hassler et al. 2013). The EU's 2008 Marine Strategy Framework Directive (MSFD; Directive 2008/56/EC) is the latest development in marine protection policies in the Baltic Sea. Mitigation measures have achieved some good results in limiting anthropogenic nutrient emissions, but the effects of the measures have been moderate; overall the eutrophication problem still remains (e.g., HELCOM 2009, Gustafsson et al. 2012)

In this paper we focus on systemic delays that cause the eutrophication problem in the Baltic Sea to persist. The causes of the delays can be found in decision-making processes, the implementation of policies, and in the marine and terrestrial ecosystems. Eutrophication in the Baltic Sea can be considered a "wicked problem" (see, e.g., Jentoft and Chuenpagdee 2009) because it is caused by emissions and drivers from multiple sources, is exacerbated by climate change and the dynamics of social and ecological systems, and resists purely technical solutions (Newton et al. 2012).

The aim of the paper is to analyze these systemic delays and especially to discuss how the critical delays can be better addressed in marine protection policies by strengthening the adaptive capacity of marine protection. The paper is based to a great degree on existing literature on dynamics of policy processes and formulation of the MSFD as well as on literature on ecosystem dynamics of the Baltic Sea. To make the argument more focused and concrete we use the EU's MSFD and its implementation in Finland, Sweden, Denmark, and Poland as empirical points of reference. The empirical material consists of the key policy documents and observations on the first steps of implementation of MSFD in those four countries (Pihlajamäki et al. 2013). We studied national implementation documents and conducted interviews with persons who coordinated the implementation processes. We also refer to HELCOM's BSAP because it is closely connected to implementation of the MSFD (e.g., Jouanneau and Raakjær 2014).

\section{ADAPTIVE MANAGEMENT UNDER UNCERTAINTIES}

Udovyk and Gilek (2013) state that difficulties in addressing uncertainties, both social and natural, are among the main challenges for the management of the Baltic Sea. They identify three strategies to address the uncertainties. The first is based on understanding uncertainty as a lack of knowledge. The policy and scientific strategy is then to reduce uncertainty through the

\footnotetext{
${ }^{1}$ Environmental Policy Centre, Finnish Environment Institute, Helsinki, Finland, ${ }^{2}$ National Marine Fisheries Research Institute, Gdynia, Poland, ${ }^{3}$ Stockholm Resilience Centre, Stockholm University, Sweden, ${ }^{4}$ Alfred Wegener Institute Helmholtz Centre for Polar and Marine Research, Wadden Sea Station Sylt, Germany, ${ }^{5}$ Marine Research Centre, Finnish Environment Institute, Helsinki, Finland, ${ }^{6}$ Department of Environmental and Business Economics, University of Southern Denmark, Denmark, ${ }^{7}$ Baltic Nest Institute, Baltic Sea Centre, Stockholm University, Sweden, ${ }^{8}$ Department of Political Science, Stockholm University, Sweden, ${ }^{9}$ Helmholtz-Zentrum Geesthacht, Germany, ${ }^{10}$ Department of Geography and Planning, University of Liverpool, UK, ${ }^{11}$ Scottish Association of Marine Science, UK, ${ }^{12}$ Department of Geography and Environment, University of Aberdeen, UK
} 
acquisition of additional data, monitoring, and research. The second strategy is to control uncertainty by applying approaches and methodologies like sensitivity analysis, modeling, and scenario building. Both strategies are based on an ideal of increasing information and improvement of knowledge-production methods to overcome the uncertainties. Scholars have observed an ever growing role of and dependency on information and knowledge in environmental decision making as a result of the developments in environmental sciences on the one hand and the nature of complex environmental problems on the other (e.g., Mol 2006, Jänicke 2008, Vink et al. 2013) The third strategy is to learn to cope with uncertainties of complex ecosystems, because they are inherent in the social-ecological system. This calls for an adaptive framework to address the uncertainties (Udovyk and Gilek 2013).

The systemic delays discussed here are a particular characteristic of the Baltic Sea system and increase the uncertainties managers have to face. Such situations require management approaches beyond traditional environmental management (Ludwig 2001). The literature on the management of complex (environmental) systems calls for adaptive approaches that are better suited to dealing with unpredictability than conventional environmental management approaches (e.g., Olsson et al. 2004, Pahl-Wostl et al. 2007, van Hoof and van Tatenhove 2009, Rijke et al. 2012). Successful adaptive approaches need to: "1) build the knowledge and understanding of resource and ecosystem dynamics, 2) develop practices that interpret and respond to ecosystem feedback, and 3) support flexible institutions and organizations and adaptive management processes" (Olsson et al. 2004:75).

The literature on adaptive management emphasizes that the management system's ability to enhance learning is a key to adaptation (Pahl-Wostl et al. 2007). This can be achieved by participatory approaches that incorporate different kinds of knowledge (Udovyk and Gilek 2013) and also through investing in the monitoring of the outcomes of actions (Pahl-Wostl et al. 2007). The literature on adaptive management suggests also structural changes in the governance of environmental issues to achieve the desired shift toward a more sustainable and effective environmental management approach (e.g., Holling 2003, Pahl-Wostl et al. 2007).

\section{SYSTEMIC DELAYS}

We highlights some of the most critical systemic delays related to the eutrophication problem. The first two types of delays, namely decision making and implementation delays, are social and political by nature, whereas the third is ecological (Fig. 1). We separate the decision making and implementation delays into different categories even though they are related. The reason for this separation is that their social and political dynamics are different.

The social and ecological delays determine how long it takes to deal with an eutrophication problem in the Baltic Sea. Because of the considerable uncertainties involved it is not possible to give an exact assessment of the length of the delays. It must be noted that there are feedbacks between the delays, but also that each of the delays has its own dynamics and internal mechanisms that can play out differently across social and ecological contexts.

\section{Decision-making delays}

A policy process is one characterized by delays. Typically it takes years to go from problem identification to negotiations and instrument selection and finally policy implementation. The exact timing will depend on the policy context in a particular time and place, the actors involved, institutional dynamics, politics, and power. Furthermore, a policy's coherence and synchronicity with other policies play a role.

Fig. 1. Types of systemic delays.

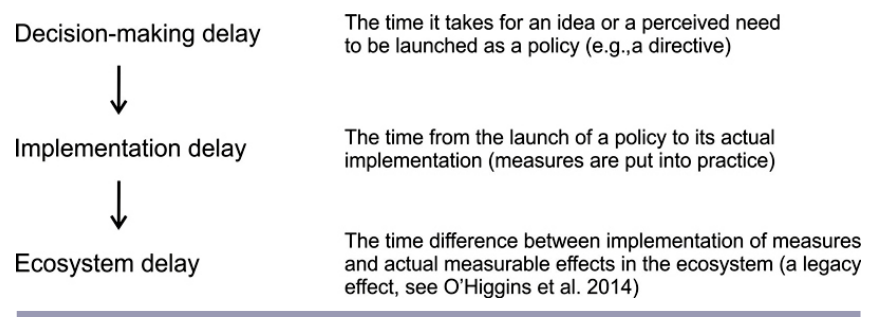

Eutrophication in the Baltic Sea is an environmental problem being addressed by the concerted efforts of several nations. First the collaboration was based on the HELCOM activities, which has in recent years been strengthened by the launch of MSFD. Several obstacles to effective international environmental policy have been identified in the literature. These stem from the characteristics of international politics and their relations with scales and dynamics of the environmental problems (Downie 2005). Agreements between several nations like the EU's MSFD increase the likelihood of significant differences in culture, environmental values, and economic and institutional development among participating states (Downie 2005). Besides the slow process of policy formulation, several factors can intervene to cause additional delays including problem identification, i.e., a lack of awareness or different definitions of the problem and possible solutions. Delays can also occur when there is a need for negotiation over the targets to be achieved, how and when to achieve the desired effect, who should be responsible and who pays, and a judicial review may also be required. Furthermore, pertaining to most of the international environmental agreements, the decisions must be made unanimously via consensus, which may further slow down the negotiation and decision-making process. Finding an acceptable compromise between negotiating parties produces a policy that is characterized by "the lowest common denominator" (Hassler 2008), which means that negotiations can only result in an agreement on a set of measures that the participating countries are willing to accept (Downie 2005).

Delays of the Marine Strategy Framework Directive

The MSFD came into force in 2008 after several years of preparation and negotiations (Long 2011). A first idea for the MSFD was introduced in 2002 (EC 2002) and the directive was initially conceived and drafted in 2005 (EC 2005). The directive stipulates that the Member States must prepare their "programme of measures" by 2015 to reach the stated goal: good environmental status (GEnS). Implementation of the programs must start in 2016. The GEnS should be reached by 2020 . The MSFD also includes six-year review cycles that are supported by monitoring programs. Regular reviews are necessary to follow the progress and to reassess the marine strategies against the developments (or inertia) in the system. The member states report on the progress to the European Commission every third year. (Juda 2010, Long 2011; see Fig. 2). 
Fig. 2. Timing of decision making and implementation of the Marine Strategy Framework Directive through phases of negotiation, preparation of implementation, and implementation. Frequent reviews allow feedback to improve implementation. The dotted line back to the negotiation phase indicates that, eventually, changes to the directive are possible (Juda 2010, Long 2011). HELCOM = The Baltic Marine Environment Protection Commission.

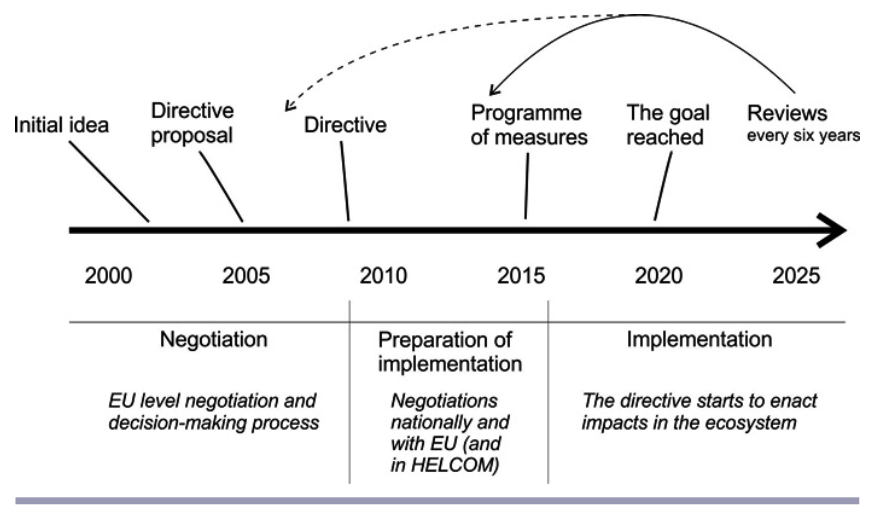

The time schedule for implementation of the directive is very tight. One year from the finalization of the program of measures (2015) to its implementation (2016) is in itself a great challenge if the national marine strategies have ambitious goals and require new or stronger mitigation measures. Ecosystem delays are a key challenge for the MSFD, which can only begin to show effects once the mitigation measures have been implemented. In some respects, and in some areas of the Baltic Sea, it may take decades before the ecosystem responses are visible.

Preparation of the MSFD took "an incredible six years" (Long 2011:9) from 2002 to 2008. This corresponds with a trend of lengthening policy formulation in the EU. For instance, Jordan et al. (1999) undertook a longitudinal analysis of the speed of EU environmental policy making during the period 1967-1997. For water policies they observed that the process slowed down considerably after 1987. Before that it took on average 900 days for a policy to come into force after the decision, whereas since 1987 the process has taken as much as 1600 days, more than four years.

Long (2011) sees that the delay in preparation of the MSFD was partly caused by opposing positions taken by environmental and economic interests in the Member States, typical in environmental policy formulation and especially complicated in international settings (Downie 2005). It has been pointed out that even though stakeholder participation in the marine decision-making process is important for the functioning of democracy, it can lead to laws being tailored to support private interests (Freire-Gibb et al. 2014). Long (2011:9) also observes that "there is little doubt that the 117 amendments to the draft instrument initially tabled by the European Parliament contributed to the delay in the lawmaking process." However, delays that are caused as a result of following a due democratic process should not automatically be seen as failures, but rather as inherent characteristics of a democratic system.
The example of time-spans of MSFD preparation applies also to HELCOM's Baltic Sea Action Plan (BSAP; HELCOM 2007a). The BSAP process started in the early 2000s, leading to its designation in 2007. The action plan was signed in 2007 by all contracting parties to the Helsinki Convention. All the parties were expected to present their national implementation plans in 2010 at the ministerial meeting in Moscow. A review of the BSAP was conducted prior to the ministerial meeting in autumn 2013 where new nutrient emission reduction targets were set (HELCOM 2013). The overall goal of the plan should be met by 2021 (Backer et al. 2010). The measures were thus given 11 years to produce the stated goals, which is more realistic than is the case with the MSFD. The BSAP is also designed to be a continuing and adaptive process that can be corrected when evidence of the effects emerges. The adaptive approach is exemplified by the recent review of the emission reduction targets.

Preparation of a policy has its internal dynamics that can cause considerable delays as was the case with MSFD and BSAP. The relationships with other policies need to be considered as well, because they may play a role in policy formulation as one expression of tensions between environmental and economic interest in the preparation of the MSFD (Long 2011). Furthermore, relationships with other policies may become a critical issue affecting policy reviews in the long run, because of the interdependence of policy sectors.

Regarding the MSFD's attempts to combat eutrophication in the Baltic Sea region, the EU's Common Agriculture Policy (CAP) is of particular importance because the reduction of nutrient loads from agriculture is to a large extent dependent on agrienvironmental measures provided by the CAP, not by the MSFD. Agriculture contributes approximately $70 \%$ to over $90 \%$ of the anthropogenic diffuse riverine nitrogen load and $60 \%-80 \%$ of the corresponding phosphorus load to the Baltic Sea (HELCOM 2011). This makes the MSFD dependent on the CAP, which underlines the importance of the issue of policy coherence. Another relevant policy development is the EU's Blue Growth policy that aims at increasing economic utilization of marine resources and space (EC 2012). It may have competing objectives with marine protection policies.

Because the coherence between policies is critical, a lack of synchrony between policies that support or jeopardize reaching objectives of marine protection policies is a possible cause of delays, especially in relation to forthcoming reviews of MSFD. The CAP and other structural funds have their own review schedules that take place over a period of seven years. The present CAP period was planned to operate from 2014 to 2020, but negotiations on the period failed, resulting in a delay of one year at the start. This has an impact on the implementation of the agrienvironmental schemes. The next MSFD review is scheduled to take place by 2021 , which is not in synchrony with the structural funds review period.

\section{Implementation delays}

Implementation delays are the time that it takes from a launch of a policy until the measures are put into practice. Delays related to the implementation of environmental policies and regulations can be triggered by societal factors stemming from a lack of resources and technical capacity as well as from a lack of incentives for action. Challenges and causes of delays during the 
first steps of implementation of the MSFD in Finland, Sweden, Denmark, and Poland elucidate these (Pihlajamäki et al. 2013). In addition, the coherence and synchronicity between policies is relevant also in the case of implementation delays. The examples discussed here elucidate specific implementation challenges for reducing nutrient emissions from municipal waste water and agriculture that are the biggest sources of nutrients in the Baltic Sea region (HELCOM 2011).

The lack of financial resources and difficulties in their costeffective allocation are evident causes of delay and have been identified as important factors in reducing the effectiveness of international environmental agreements (Downie 2005). However, in the new EU Member States, especially in Lithuania, Latvia, and Poland, the lack of human resources, expertise, and technical capacity also affect the capabilities of the national environmental administrations to implement environmental policies, including water protection measures (Jokela 2011, Dmochowska and Szaniawska 2011). Pertaining to MSFD, Long (2011) observes that the failure of most of the EU member states to transpose the MSFD directive into legislations could suggest further delays in the implementation of the directive. The delays "may indicate an absence of political will, resources or simple administrative capability to bring into force the [directive]" (Long 2011:42).

Our findings from Finland, Sweden, Denmark, and Poland support those observations. All of the four countries failed to meet a requirement of transposing the MSFD into national legislations by 15 July 2010 . The delays ranged from four months (Sweden) to almost three years (Poland; Pihlajamäki et al. 2013, EC 2014). As the first steps of implementation of the MSFD the member states were also required to conduct initial assessment of the state of the marine environment (article 8), determine good environmental status (GEnS; article 9), and set environmental targets and indicators (article 10; Directive 2008/56/EC). None of the four countries did that by the set deadline of 15 July 2012, although Denmark and Sweden could report their progress already during the autumn of 2012 (Pihlajamäki et al. 2013) and Finland by April 2013 (EC 2014). Poland had not reported by April 2014 when the EU Commission published a report on implementation status of the MSFD (EC 2014). Interviews and analysis of documents (presented in more detail in Pihlajamäki et al. 2013) showed that the main problems encountered during the preparatory phase in the four studied countries related to a lack of financial and human resources, but also to a lack of data (or limited access to it), methodological issues on determining the GEnS. Another problem stems from a novelty of the concept of a national marine strategy; there were no detailed guidelines how the strategies are supposed to be prepared. Therefore, during the preparation of the national marine strategies, much of the time of the experts involved was spent in different EU working groups, with the aim of producing a common understanding on the requirements of the directive and how the marine strategies are to be prepared. In the Baltic Sea region HELCOM working groups also were dedicated to coordinate the scientific work on the marine strategies (see also Jouanneau and Raakjær 2014). Nevertheless, the decisions on how to pursue the preparatory work were made at national levels and revised as new information about the requirements of the directive, including reporting requirements, emerged. This lead to very different approaches in different member states (Pihlajamäki et al. 2013).
In addition to delays implementing a new policy, implementation delays are created by the cyclical nature of the policy implementation that differs considerably from policy to policy and depends on the periodicity of decision making (Downie 2005). In the case of eutrophication, this is also strongly related to the issue of coherence and synchronicity with other policies. The implementation of policies can be planned to operate periodically when reviews to check progress toward goals are planned beforehand as in the MSFD. In some other cases, e.g., the EU's Common Agricultural Policy, the policies are planned for a certain period, after which a reform of the policy will take place and possibly lead to substantial changes in the policy. This has implication on long-term coherence and synchronicity of policies and can result as decision-making delays, but the periodicity of policies operates also in shorter cycles creating delays for practical implementation of the policies.

We discuss examples of the shorter cycles relevant for combatting eutrophication in the Baltic Sea. The examples relate to attempts to reduce nutrient emissions from municipalities and from agriculture. Environmental permits that regulate nutrient emissions of point sources are often given for several years at a time and are renewed periodically. Therefore, even if new knowledge emerges during the permit period, an intervention is difficult, if not impossible. For example, in many of the Finnish Waste Water Treatment Plants (WWTP), nitrogen removal efficiency is still below the $70 \%$ requirement of the EU directive on urban waste water treatment (see, e.g., Säylä and Vilpas 2012, Pietiläinen 2008). According to the Finnish Environmental Protection Act, the need for more efficient removal is determined in the environmental permit procedure individually for each plant, and the renewal of all permits has not yet been scheduled. In cases where nitrogen removal from the WWTPs is required, the reduction must be made operational within seven years from the establishment of the permit. This implies further delays in the improvement of the overall nitrogen removal efficiency from the Finnish WWTPs. The recently revised nutrient emission reduction targets by HELCOM (HELCOM 2013) stipulated more stringent nitrogen removal targets. With the existing environmental permits of the WWTPs, implementation of the new targets cannot be immediate.

Farmers are required to reduce nutrient losses from their fields, but implementation of the most effective measures depends on the willingness of the farmers, which is to a large extent determined by the availability of incentives that encourage taking action (Buckley et al. 2012). Regarding agriculture measures, the periodicity of agriculture policies may create significant delays in the process even if the farmers are willing to take action. Within the agri-environmental schemes, farmers are required to make a long-term commitment to a set of measures for the entire program period (e.g., 2007-2013), regardless of whether the measures later prove to be effective or not (Pihlajamäki 2011). Thus, the rigidity of the scheme prevents the use of the best available knowledge of the most suitable practices as well as technical solutions during the program period. While the periodicity of agri-environmental schemes reduces flexibility, there are also problems in terms of long-term continuity, because the conditions for the contracts are renegotiated every seven years.

Finally, problems in implementing policies can stem from general societal issues (Downie 2005, Buckley et al. 2012). These problems 
are the least predictable. Regarding the MSFD it has been noted that "even though private sector lobbying is not a problem per se for implementing the MSFD, particular problems regarding MSFD implementation could arise if these sectors choose to confront or avoid MSFD goals" (Freire-Gibb et al. 2014:5).

\section{Ecosystem delays}

We describe ecosystem mechanisms that cause delays in the response of the Baltic Sea ecosystem to the application of measures to reduce nutrient loads. These exemplify the time lags in recovery from eutrophic status. They describe processes in the marine ecosystem itself and nutrient loss abatement on agricultural land, and they illustrate examples of both memory and future effects (O'Higgins et al. 2014).

\section{Memory effects in the Baltic Sea}

Despite the observed decrease in water-borne nutrient loading due to measures taken to reduce the discharge of nutrients in the Baltic Sea (HELCOM 2011), positive large-scale effects have not been observed (HELCOM 2009, Gustafsson et al. 2012). Part of this delay in the reduction of the eutrophic level can be explained by internal processes. Eutrophication leads to increased sedimentation of organic material, which, after deposition in the deep Baltic Sea basins, increases oxygen consumption and subsequently leads to anoxic bottoms and anoxic deep-water masses. This, in turn, results in the release of phosphorus from sediments to water masses and the reduction of nitrates to nitrites and ammonia, therefore preventing denitrification. (Fonselius 1969, Wulff et al. 1990, Conley et al. 2002, Slomp 2008, Vahtera et al. 2007). Further, deep-water oxygen concentrations in the Baltic Sea are mainly influenced by saltwater inflows that contain oxygen from the North Sea. The lack of saltwater inflows exacerbates the internal loading processes. The latest significant inflows took place in 1993 and 2003 (HELCOM 2007b).

Future effects - ecosystem delays in agricultural soils

Another cause of delay is the time lag between the reduction in the application of fertilizers in agriculture and the reduction in the concentration of nutrients in rivers and consequently in the Baltic Sea. This delay is caused by biochemical processes in soil. A slow and limited response has been observed in several studies (Stålnacke et. al. 2004, Pastuszak et al. 2012). The response of the system to reduced pressure varied from 5 to 15 years (Dannowski et al. 2002). As for phosphorous, studies have revealed that riverine loads of this element can be rapidly reduced from high to moderate levels, whereas a further reduction, if achieved at all, may take decades (Grimvall et al. 2000).

\section{Ecological consequences of the delays}

Consequences of these memory and future effects (see O'Higgins et al. 2014) can be observed, for instance, in open sea areas as frequent blooms of cyanobacteria (Wulff et al. 1990, Vahtera et al. 2007) and in coastal areas as slow recovery of seagrass beds in the Baltic Sea (Munkes 2005, HELCOM 2007c, Nyqvist et al. 2009, Baden et al. 2012). Seagrass beds are highly important for coastal ecosystems because they fulfil a great variety of ecological functions (Larkum et al. 2006). Seagrass beds are particularly sensitive to eutrophication (Burkholder et al. 2007, van Katwijk et al. 2010). Nutrient reduction measures have been applied, but seagrass recovery has not been observed in the Baltic Sea for various possible reasons (Munkes 2005, HELCOM 2007c,
Nyqvist et al. 2009, Baden et al. 2012), despite promising examples elsewhere (e.g., Bryars and Neverauskas 2004, Tomasko et al. 2005, Orth et al. 2006, Cardoso et al. 2010, Vaudrey et al. 2010, Dolch et al. 2013). Seagrass recovery is generally a slow process, which can last for decades, and it is questionable whether the ecosystem can ever be returned to its original state.

These examples of delayed ecosystem responses to measures to combat eutrophication in the Baltic Sea illustrate that in some situations feedbacks keep the ecosystem in a certain state and cause the delay in the ecosystem response, a phenomenon that is called hysteresis (Scheffer et al. 2001). An added and unpredictable factor is that in some cases there is no return to the previous state, a situation that has been termed "shifting baseline" (Duarte et al. 2009).

However, in some areas of the Baltic Sea, e.g., the Kattegat and Belt Sea region, a decreasing trend in primary production since 1980 (Rydberg et al. 2006) and a slower increase in nutrient levels in recent decades, as compared with the 1970s-1990s (Papush and Danielsson 2006), are signs of ecosystem recovery, possibly in response to reduced point sources and agricultural pollution (Olli et al. 2011). In other areas, such as many coastal bays, this trend cannot be seen (Duarte et al. 2009, Gustafsson et al. 2012). Here, positive feedbacks prevent the phytoplankton biomass from decreasing, even though the nutrients loads have been decreased.

Because of the substantial uncertainties involved, it is not possible to determine the exact duration of an ecosystem delay, but these phenomena operate on decadal scales. The issue of a "shifting baseline" changes the situation considerably because the possible ecosystem response has to be regarded from a differentiated perspective. In such a case the policy target may have to be redefined. It is also important to note that these ecosystem delays are specific to certain parts of and locations in the Baltic Sea. Different parts of the sea "behave" differently, depending on their geographical position and ecological characteristics, which further complicates the finding of evidence of results in attempts to combat eutrophication

\section{SUGGESTIONS FOR PROCESSES TO ADDRESS THE SYSTEMIC DELAYS}

Ecosystem delays make eutrophication difficult to deal with, but as was shown above the delays in the policy area, including lengthy decision making, mismatches of policies, and lack of implementation, also contribute to the difficulties. The combined result is nonalignment of policy/management cycles and ecosystem responses and possibly "implementation frustration" and the danger of wrong action at the wrong time.

Finding remedies for the observed delays is difficult. As was pointed out at the beginning of this paper, dealing with systemic delays requires an adaptive, learning approach (Olsson et al. 2004, Udovyk and Gilek 2013). The literature on adaptive management calls for substantial structural changes in the governance of environmental issues to enhance the desired changes and shift them toward more sustainable and effective environmental management approach (e.g., Holling 2003, Pahl-Wostl et al. 2007). The systemic delays pertaining to the eutrophication problem pose, however, a specific problem here: do the delays in meeting the desired goals exist because of or despite the present, possibly flawed, institutions? The ecosystems' slow response to 
mitigation measures complicates the monitoring and evaluation of policies, an integral part of adaptive management, because it is not easy to conclude whether a policy is appropriate and effective or whether the goal was unrealistic in the first place. We conclude that instead of expediting the substantial structural changes in governance systems called for in the adaptive management literature, dealing with delays necessitates improved monitoring of both effects and implementation of policies and participatory, deliberative practices to cope with the problem to build an understanding of the ecological and social aspects of the system that is managed (Udovyk and Gilek 2013). This emphasizes the social learning aspects also highlighted in the adaptive management literature (Pahl-Wost et al. 2007).

Adaptive management is a learning process, which is required for dealing with situations that are inherently uncertain or change quickly. The systemic delays in eutrophication and its management are an example of such uncertainties. Investing in the monitoring of the outcomes of actions is necessary to enable learning in a complex and wicked situation (Pahl-Wostl et al. 2007).

There are common indicators and parameters to determine the level of eutrophication, such as Secchi depth (a measure of transparency of water), and concentrations of Chlorophyll-a or nutrients, in particular nitrogen and phosphorous. Eutrophication can also be assessed by using seagrass as an indicator, e.g., in the EU Water Framework Directive (Foden and Brazier 2007, Krause-Jensen et al. 2005, Romero et al. 2007). Monitoring of ecosystem delays can be conducted by determining the time difference between the actual measures, i.e., the reduction of nutrient discharge (source), and a measurable improvement in the ecological situation in the sea (sink). In this regard it is crucial which parameter or indicator is taken to detect mitigation. For example, after nutrient loads were considerably reduced in the southwestern Baltic Sea over a period of 15 years, the light conditions measured by the Secchi depth improved slightly while seagrass showed no recovery. The question remains as to whether the recovery time is just prolonged or if other factors intervene the development. This calls for continued monitoring, but also better understanding of the functioning of the system because effects, or the lack of them, that are detected can be caused by multiple factors. In addition, there is the concern that a baseline shift takes place (Duarte et al. 2009).

Monitoring typically focuses on the state, but more attention needs to be given to the monitoring of implementation as a key element of adaptive management and learning (Douvere and Ehler 2011). The delays in the ecosystem make direct monitoring of the effects of policy very difficult. Therefore, there is a need to monitor the implementation of measures and to conduct research on social dynamics of implementation. In other words, adaptive management needs so called "process indicators" (Ehler 2003). Presently the MSFD (Article 11 and Annex V) and respective guidance (Zampoukas et al. 2012) calls for monitoring of the environmental status of marine waters. However, there already is a plethora of modeling and experimental research on the effectiveness of measures to combat eutrophication (e.g., Puustinen et al. 2010), which would allow for the estimating or modeling of the future effects of the policies.

Udovyk and Gilek (2013) call for specific methods to deal with uncertainties. Greater awareness of delays through monitoring is necessary to improve knowledge of the problem, but as they emphasize there is a need to increase capacity to deal with persistent uncertainties through participatory processes. Hassler et al. (2013) points out that environmental monitoring of the state of the Baltic Sea is well developed and is at a high level, thanks to long-term efforts by HELCOM. They suggest that in addition to scientific monitoring, the participation of a wide group of actors in the monitoring and assessment of marine governance should be enhanced, because "various sets of stakeholders commanding different sources of knowledge and experiences can contribute to the long-term robustness of environmental governance" (Hassler et al. 2013:241). Reflecting on the application of protection measures with the stakeholders whose actions the policy aims to change would help to understand a broad range of factors, e.g., other related policies or economic incentives, that influence willingness and realistic opportunities to reduce emissions. An additional benefit of such collaboration would be heightened awareness of the related dynamics of implementation and effectiveness of the measures among the managers and the actors who implement the measures. Involvement of stakeholders into planning and development of policy measures are at the crux of adaptive management (PahlWostl et al. 2007, Rijke et al. 2012). Because the ecosystem effects may become measurable after several decades, monitoring and research of implementation, in combination to estimates of future effects, would provide early feedback to improve performance of policies. Research and monitoring of ecosystem dynamics would then help to improve understanding of uncertainties pertaining to the ecosystem dynamics as illustrated in Figure 3. The cyclical nature of policies with subsequent reviews even though if left uncoordinated is a source of nonsynchrony provides an opportunity of strengthening adaptive aspects of policies. Considering the MSFD, the frequent reviews and reporting should be taken as opportunities in the member states and in the EU to increase understanding of the system dynamics.

Fig. 3. Feedbacks and learning provided by research and monitoring of ecosystem effects and implementation.

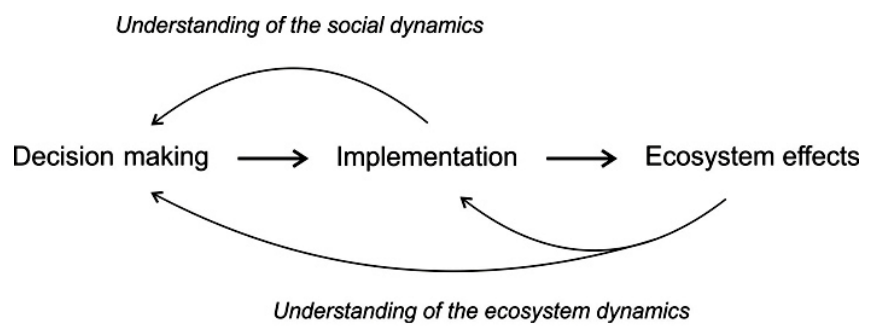

The analyses of decision making and implementation delays show that social and political dynamics make an important contribution to the emergence of delays, for instance by creating so called choke points (covered in Potts et al. 2015). We maintain that reflexive and participatory approaches in the development of marine protection policies, the monitoring of their implementation and effects would create forums to: "1) build the knowledge and understanding of resource and ecosystem dynamics, 2) develop practices that interpret and respond to ecosystem feedback, and 3) support flexible institutions and organizations and adaptive management processes" (Olsson et al. 
2004:75) that are the cornerstones of adaptive management. Reflexive and participatory approaches would help to mitigate against conflicts of interests, coordinating between policies, addressing unequal allocation of costs of protection, and identifying corrective measures.

Responses to this article can be read online at: http://www.ecologyandsociety.org/issues/responses. $\mathrm{php/6938}$

\section{Acknowledgments:}

The research leading to this paper has received funding from the European Community's Seventh Framework Programme [FP7/2007-2013] under grant agreement number 226675 "Knowledge-based Sustainable Management for Europe's Seas." The research was funded also by grants from the Swedish Research Council Formas Project "Regime Shifts in the Baltic Sea Ecosystem" and the strategic program at Stockholm University "Baltic Ecosystem Adaptive Management Program." Research presented in this paper contributes to the Nordic Centre for Research on Marine Ecosystems and Resources under Climate Change (NorMER), which is funded by the Norden Top-level Research Initiative subprogram "Effect Studies and Adaptation to Climate Change." The authors are grateful to the two anonymous reviewers whose critical comments helped to improve the paper substantially.

\section{LITERATURE CITED}

Backer, H., J.-M. Leppänen, A. C. Brusendorff, K. Forsius, M. Stankiewicz, J. Mehtonen, M. Pyhälä, M. Laamanen, H. Paulomäki, N. Vlasov, and T. Haaranen. 2010. HELCOM Baltic Sea Action Plan - a regional programme of measures for the marine environment based on the Ecosystem Approach. Marine Pollution Bulletin 60:642-649. http://dx.doi.org/10.1016/j. marpolbul.2009.11.016

Baden, S., A. Emanuelsson, L. Pihl, C.-J. Svensson, and P. Åberg. 2012. Shift in seagrass foodweb structure over decades is linked to overfishing. Marine Ecology Progress Series 451:61-73. http:// dx.doi.org/10.3354/meps09585

Buckley, C., S. Hynes, and S. Mechan. 2012. Supply of an ecosystem service-farmers' willingness to adopt riparian buffer zones in agricultural catchments. Environmental Science \& Policy 24:101-109. http://dx.doi.org/10.1016/j.envsci.2012.07.022

Burkholder, J. M., D. A. Tomasko, and B. W. Touchette. 2007. Seagrasses and eutrophication. Journal of Experimental Marine Biology and Ecology 350:46-72. http://dx.doi.org/10.1016/j. jembe.2007.06.024

Bryars, S., and V. Neverauskas. 2004. Natural recolonisation of seagrasses at a disused sewage sludge outfall. Aquatic Botany 80:283-289. http://dx.doi.org/10.1016/j.aquabot.2004.09.001

Cardoso, P. G., S. Leston, T. F. Grilo, M. D. Bordalo, D. Crespo, D. Raffaelli, and M. A. Pardal. 2010. Implications of nutrient decline in the seagrass ecosystem success. Marine Pollution Bulletin 60:601-608. http://dx.doi.org/10.1016/j.marpolbul.2009.11.004
Conley, J. D., C. Humborg, L. Rahm, O. P. Savchuk, and F. Wulff. 2002. Hypoxia in the Baltic Sea and basin-scale changes in phosphorous biogeochemistry. Environmental Science and Technology 36:5315-5320. http://dx.doi.org/10.1021/es025763w

Dannowski, R., J. Steidl, W. Mioduszewski, and I. Krajewski. 2002. GIS-based distributed analysis of subsurface nitrogen flow in the Odra basin. Journal of Water and Land Development 6:91-104.

Dmochowska, B., and A. Szaniawska. 2011. Poland looking for a higher environmental awareness. Pages 66-77 in M. Pihlajamäki and N. Tynkkynen, editors. Governing the blue-green Baltic Sea. Societal challenges of marine eutrophication prevention. FIIA report 31. The Finnish Institute for International Affairs, Helsinki, Finland.

Dolch, T., C. Buschbaum, and K. Reise. 2013. Persisting intertidal seagrass beds in the northern Wadden Sea since the 1930s. Journal of Sea Research 82:134-141. http://dx.doi.org/10.1016/j. seares.2012.04.007

Douvere, F., and C. N. Ehler. 2011. The importance of monitoring and evaluation in adaptive maritime spatial planning. Journal of Coastal Conservation 15:305-311. http://dx.doi.org/10.1007/ s11852-010-0100-9

Downie, D. L. 2005. Global environmental policy: governance through regimes. Pages 70-91 in R. Axelrod, D. L. Downie, and N. Vig, editors. The global environment: institutions, law, and policy. CQ Press, Washington, D.C., USA.

Duarte, C. M., D. J. Conley, J. Carstensen, and M. SánchezCamacho. 2009. Return to Neverland: shifting baselines affect eutrophication restoration targets. Estuaries and Coasts 32:29-36. http://dx.doi.org/10.1007/s12237-008-9111-2

Ehler, C. N. 2003. Indicators to measure governance performance in integrated coastal management. Ocean \& Coastal Management 46:335-345. http://dx.doi.org/10.1016/S0964-5691(03)00020-6

European Commission (EC). 2002. Towards a strategy to protect and conserve the marine environment. $\mathrm{COM}(2002) 539$ final. European Commission, Brussels, Belgium.

European Commission (EC). 2005. Thematic strategy on the protection and conservation of the marine environment. European Commission, Brussels, Belgium.

European Commission (EC). 2012. Blue growth-opportunities for marine and maritime sustainable growth. European Commission, Brussels, Belgium.

European Commission (EC). 2014. Annex accompanying the document The first phase of implementation of the Marine Strategy Framework Directive. Commission Staff Working Document, SWD(2014) 49 final. European Commission, Brussels, Belgium.

Foden, J., and D. P. Brazier. 2007. Angiosperms (seagrass) within the EU water framework directive: a UK perspective. Marine Pollution Bulletin 55:181-195. http://dx.doi.org/10.1016/j. marpolbul.2006.08.021

Fonselius, S. H. 1969. Hydrography of the Baltic Deep Basins. Series Hydrography. Fishery Board of Sweden, Stockholm, Sweden. 
Freire-Gibb, L. C., R. Koss, P. Margonski, N. Papadopoulou. 2014. Governance strengths and weaknesses to implement the marine strategy framework directive in European waters. Marine Policy 44:172-178. http://dx.doi.org/10.1016/j.marpol.2013.08.025

Grimvall, A., P. Stålnacke, and A. Tonderski. 2000. Time scales of nutrient losses from land to sea - a European perspective. Ecological Engineering 14:363-371. http://dx.doi.org/10.1016/ $\underline{\mathrm{S} 0925-8574(99) 00061-0}$

Gustafsson, B. G., F. Schenk, T. Blenckner, K. Eilola, H. E. Meier, B. Müller-Karulis, T. Neumann, T. Ruoho-Airola, O. P. Savchuk, and E. Zorita. 2012. Reconstructing the development of Baltic Sea eutrophication 1850-2006. Ambio 41:534-548. http://dx.doi. org/10.1007/s13280-012-0318-X

Hassler, B. 2008. Environmental conventions, pro-active countries and unilateral initiatives-Sweden and the case of oil transportation on the Baltic Sea. Journal of Environmental Policy \& Planning 10:339-357. http://dx.doi.org/10.1080/15239080802331986

Hassler, B., M. Boström, and S. Grönholm. 2013. Towards an ecosystem approach to management in regional marine governance? The Baltic Sea context. Journal of Environmental Policy \& Planning 15:225-245. http://dx.doi.org/10.1080/1523908X.2013.766420

HELCOM 2007a. HELCOM Baltic Sea action plan. Baltic Marine Environment Protection Commission, Helsinki, Finland.

HELCOM, 2007b. Climate change in the Baltic Sea area. HELCOM Thematic Assessment in 2007. Baltic Sea Environment Proceedings No. 111. Baltic Marine Environment Protection Commission, Helsinki, Finland.

HELCOM 2007c. HELCOM lists of threatened andlor declining species and biotopes/habitats in the Baltic Sea area. Baltic Sea Environmental Proceedings No. 113. Baltic Marine Environment Protection Commission, Helsinki, Finland.

HELCOM 2009. Eutrophication in the Baltic Sea: an integrated thematic assessment of the effects of nutrient enrichment in the Baltic Sea region. Baltic Sea Environment Proceedings No. 115B. Baltic Marine Environment Protection Commission, Helsinki, Finland.

HELCOM 2011. The Fifth Baltic Sea Pollution Load Compilation (PLC5). Baltic Sea Environment Proceedings No. 128. Baltic Marine Environment Protection Commission, Helsinki, Finland.

HELCOM 2013. Summary notes for the 2013 HELCOM Ministerial Declaration. Baltic Marine Environment Protection Commission, Helsinki, Finland.

Holling, C. S. 2003. Foreword: the back-loop to sustainability. Pages Xv-xxi in F. Berkes, J. Colding, and C. Folke. Navigating social-ecological systems. Building resilience for complexity and change. Cambridge University Press, Cambridge, UK.

Jänicke, M. 2008. Ecological modernisation: new perspectives. Journal of Cleaner Production 16:557-565. http://dx.doi. org/10.1016/j.jclepro.2007.02.011
Jentoft, S.,and R. Chuenpagdee. 2009. Fisheries and coastal governance as a wicked problem. Marine Policy 33:553-560. http://dx.doi.org/10.1016/j.marpol.2008.12.002

Jokela, M. 2011. The Baltic States at crossroads of different environmental development paths. Pages 55-65 in M. Pihlajamäki and N. Tynkkynen, editors. Governing the blue-green Baltic Sea. Societal challenges of marine eutrophication prevention. FIIA report 31. The Finnish Institute for International Affairs, Helsinki, Finland.

Jordan, A., R. Brouwer, and E. Noble. 1999. Innovative and responsive? A longitudinal analysis of the speed of EU environmental policy making, 1967-97. Journal of European Public Policy 6:376-398. http://dx.doi.org/10.1080/135017699343586

Jouanneau, C., and J. Raakjær. 2014. 'The Hare and the Tortoise': lessons from Baltic Sea and Mediterranean Sea governance. Marine Policy 50:331-338. http://dx.doi.org/10.1016/j.marpol.2014.03.006

Juda, L. 2010. The European Union and the Marine Strategy Framework Directive: continuing the development of European ocean use management. Ocean Development \& International Law 41:34-54. http://dx.doi.org/10.1080/00908320903285463

Krause-Jensen, D., T. M. Greve, and K. Nielsen. 2005. Eelgrass as a bioindicator under the European Water Framework Directive. Water Resources Management 19:63-75. http://dx.doi. org/10.1007/s11269-005-0293-0

Larkum, W. D., R. J. Orth, and C. M. Duarte. 2006. Seagrasses, biology, ecology and conservation. Springer, Heidelberg, Germany.

Long, R. 2011. The Marine Strategy Framework Directive: a new European approach to the regulation of the marine environment, marine natural resources and marine ecological services. Journal of Energy \& Natural Resources Law 29:1-44.

Ludwig, D. 2001. The era of management is over. Ecosystems 4:758-764. http://dx.doi.org/10.1007/s10021-001-0044-x

Mol, A. P. J. 2006. Environmental governance in the information age: the emergence of informational governance. Environment and Planning C: Government and Policy 24:497-514. http://dx.doi. org/10.1068/c0508j

Munkes, B. 2005. Eutrophication, phase shift, the delay and the potential return in the Greifswalder Bodden, Baltic Sea. Aquatic Science 67:372-381. http://dx.doi.org/10.1007/s00027-005-0761$\underline{x}$

Newton, A., T. J. B. Carruthers, and J. Icely. 2012. The coastal syndromes and hotspots on the coast. Estuarine, Coastal and Shelf Science 96:39-47. http://dx.doi.org/10.1016/j.ecss.2011.07.012

Nyqvist, A., C. André, M. Gullström, S. P. Baden, and P. Åberg. 2009. Dynamics of seagrass meadows on the Swedish Skagerrak coast. Ambio 38:85-88.> http://dx.doi.org/10.1579/0044-7447-38.2.85

O’Higgins, T., P. Cooper, E. Roth, A. Newton, A. Farmer, I. C. Goulding, and P. Tett. 2014. Temporal constraints on ecosystem management: definitions and examples from Europe's regional seas. Ecology and Society 19(4): 46. http://dx.doi.org/10.5751/ $\underline{\text { ES-06507-190446 }}$ 
Olli, K., R. Klais, T. Tamminen, R. Ptacnik, and T. Andersen. 2011. Long term changes in the Baltic Sea phytoplankton community. Boreal Environment Research 16:3-14.

Olsson, P., C. Folke and F. Berkes 2004. Adaptive comanagement for building resilience in social-ecological systems. Environmental Management 34:75-90. http://dx.doi.org/10.1007/s00267-003-0101-7

Orth, R. J., T. J. B. Carruthers, W. C. Dennison, C. M. Duarte, J. W. Fourqurean, K. L. Heck Jr., A. R. Hughes, G. A. Kendrick, W. J. Kenworthy, S. Olyarnik, F. T. Short, M. Waycott, and S. L. Williams. 2006. A global crisis for seagrass ecosystems. Bioscience 56:987-996. http://dx.doi.org/10.1641/0006-3568(2006)56[987: AGCFSE]2.0.CO;2

Pahl-Wostl, C., J. Sendzimir, P. Jeffrey, J. Aerts, G. Berkamp, and K. Cross. 2007. Managing change toward adaptive water management through social learning. Ecology and Society 12(2): 30. [online] URL: http://www.ecologyandsociety.org/vol12/iss $2 /$ $\underline{\operatorname{art} 30 /}$

Papush, L., and A. Danielsson. 2006. Silicon in the marine environment: dissolved silica trends in the Baltic Sea. Estuarine, Coastal and Shelf Science 67:53-66. http://dx.doi.org/10.1016/j. ecss.2005.09.017

Pastuszak, M., T. Kowalkowski, and J. Igras. 2012. Nitrogen and phosphorous emission into the Vistula and Oder Basins. Pages 265-354 in M. Pastuszak and J. Igras, editors. Temporal and spatial differences in emission of nitrogen and phosphorous from Polish territory to the Baltic Sea. National Marine Fisheries Research Institute, Gdynia, Poland.

Pietiläinen, O.-P., editor. 2008. Yhdyskuntien typpikuormitus ja pintavesien tila. The Finnish Environment 46/2008. Finnish Environment Institute, Helsinki, Finland.

Pihlajamäki, M. 2011. Finland - no easy solutions left. Pages 100-111 in M. Pihlajamäki and N. Tynkkynen, editors. Governing the blue-green Baltic Sea. Societal challenges of marine eutrophication prevention. FIIA report 31. The Finnish Institute for International Affairs, Helsinki, Finland.

Pihlajamäki, M., R. Varjopuro, M. Nekoro, M. Valman, E. Roth, I. Psuty, E. Andrulewicz, W. Pelczarski, A. Luzeńczyk, and N. Hyvärinen. 2013. Deliverable D7.3: Marine Strategies for the Baltic Sea. First steps in the implementation of MSFD in Denmark, Poland, Finland and Sweden. KnowSeas Project, Scottish Association for Marine Science, Oban, UK. [online] URL: http:// www.msfd.eu/knowseas/library/D7.3.pdf

Potts, T., T. O'Higgins, R. Brennan, S. Cinnirella, U. Steiner Brandt, J. De Vivero, J. Beusekom, T. A. Troost, L. Paltriguera and A. Hosgor. 2015. Detecting critical choke points for achieving Good Environmental Status in European Seas. Ecology and Society, in press Vol. 20 Issue 1.

Puustinen, M., E. Turtola, M. Kukkonen, J. Koskiaho, J. Linjama, R. Niinioja, and S. Tattari. 2010. VIHMA-A tool for allocation of measures to control erosion and nutrient loading from Finnish agricultural catchments. Agriculture, Ecosystems and Environment 138:306-317. http://dx.doi.org/10.1016/j.agee.2010.06.003

Rijke, J., R. Brown, C. Zevenbergen, R. Ashley, M. Farrelly, P. Morison, and S. van Herk. 2012. Fit-for-purpose governance: a framework to make adaptive governance operational. Environmental Science \& Policy 22:73-84. http://dx.doi. org/10.1016/j.envsci.2012.06.010

Romero, J., B. Martínez-Crego, T. Alcoverro, and M. Pérez. 2007. A multivariate index based on the seagrass Posidonia oceanica (POMI) to assess ecological status of coastal waters under the water framework directive (WFD). Marine Pollution Bulletin 55:196-204. http://dx.doi.org/10.1016/j.marpolbul.2006.08.032

Rydberg, L., G. Ærtebjerg, and L. Edler. 2006. Fifty years of primary production measurements in the Baltic entrance region, trends and variability in relation to land-based input of nutrients. Journal of Sea Research 56:1-16. http://dx.doi.org/10.1016/j. seares.2006.03.009

Säylä, J., and R. Vilpas. 2012. Yhdyskuntien jätevesien puhdistus 2010. Suomen ympäristökeskuksen raportteja 21/2012. Finnish Environment Institute, Helsinki, Finland.

Scheffer, M., S. Carpenter, J. A. Foley, C. Folke, and B. Walker. 2001. Catastrophic shifts in ecosystems. Nature 413:591-596. http://dx.doi.org/10.1038/35098000

Slomp C. P. 2008. Effect of hypoxia on the biogeochemical cycle of phosphorus. Pages 16-17 in L. Zillén, D. Conley, E. Bonsdorff, and B.-M. Jakobsen. Hypoxia in the Baltic Sea. Final Report from the Baltic 2020 project. BalticSea2020, Stockholm, Sweden. [online] URL: http://www.balticsea2020.org/english/images/ Bilagor/coley $\% 20$ ecoengi $\% 20$ final $\% 20$ report.pdf

Stålnacke P., S. M. Vandsemb, A. Vassiljev, A. Grimvall, and G. Jolankai. 2004. Changes in nutrient levels in some Eastern European Rivers in response to large-scale changes in Agriculture. Water Science and Technology 49:29-36.

Tomasko, D. A., C. A. Corbett, H. S. Greening, and G. E. Raulerson. 2005. Spatial and temporal variation in seagrass coverage in Southwest Florida: assessing the relative effects of anthropogenic nutrient load reductions and rainfall in four contiguous estuaries. Marine Pollution Bulletin 50:797-805. http:// dx.doi.org/10.1016/j.marpolbul.2005.02.010

Udovyk, O., and M. Gilek. 2013. Coping with uncertainties in science-based advice informing environmental management of the Baltic Sea. Environmental Science \& Policy 29:12-23. http:// dx.doi.org/10.1016/j.envsci.2013.01.015

Vahtera, E., D. J. Conley, B. G. Gustafsson, H. Kuosa, H. Pitkänen, O. P. Savchuk, T. Tamminen, M. Viitasalo, M. Voss, N. Wasmund, and F. Wulff. 2007. Internal ecosystem feedbacks enhance nitrogen-fixing cyanobacteria blooms and complicate management in the Baltic Sea. Ambio 36:186-194. http://dx.doi. org/10.1579/0044-7447(2007)36[186:IEFENC]2.0.CO;2

van Hoof, L., and J. van Tatenhove 2009. EU marine policy on the move: the tension between fisheries and maritime policy. Marine Policy 33:726-732. http://dx.doi.org/10.1016/j.marpol.2009.02.007

van Katwijk, M. M., A. R. Bos, P. Kennis, and R. de Vries. 2010. Vulnerability to eutrophication of a semi-annual life history: a lesson learnt from an extinct eelgrass (Zostera marina) population. Biological Conservation 143:248-254. http://dx.doi. org/10.1016/j.biocon.2009.08.014 
Vaudrey, J. M. P., J. N. Kremer, B. F. Branco, and F. T. Short. 2010. Eelgrass recovery after nutrient enrichment reversal. Aquatic Botany 93:237-243. http://dx.doi.org/10.1016/j. aquabot.2010.08.005

Vink, M. J., A. Dewulf and C. Termeer. 2013. The role of knowledge and power in climate change adaptation governance: a systematic literature review. Ecology and Society 18(4): 46. http:// dx.doi.org/10.5751/ES-05897-180446

Wulff F., A. Stigebrandt, and L. Rahm. 1990. Nutrient dynamics of the Baltic Sea. Ambio 19:126-133.

Zampoukas, N., H. Piha, E. Bigagli, N. Hoepffner, G. Hanke, and A. C. Cardoso. 2012. Monitoring for the Marine Strategy Framework Directive: requirements and options. JRC Scientific and Technical Reports. European Commission, Joint Research Centre, Ispra, Italy. 